\title{
Website Dimensions And E-Trust, Disposition, Perceived Risk, And Online Self-Efficacy: Technology Acceptance Model in China and Ivory Coast Context
}

\author{
Prof: LI ZHI WEN \\ School of Management, Jiangsu University \\ PO box: 212013, Zhenjiang, 01 Xuefu Road, Jiangsu Province, China. \\ AKOUATCHA GUY HAROLD Phd Student \\ School of Management, Jiangsu University \\ PO box: 212013, Zhenjiang, 01 Xuefu Road, Jiangsu Province, China \\ EPEZAGNE ASSAMALA INGRID RUTH Mba Student \\ School of Management, Jiangsu University \\ PO box: 212013, Zhenjiang, 01 Xuefu Road, Jiangsu Province, China
}

\begin{abstract}
Recent technological advancement and easy access to internet led to great improvements in business performances, especially the banking sector. The internet enables efficient transactions on hand-held gadgets such as smart phones and personal computers. Though there are numerous benefits, fraud and cyber-crimes via online system created scepticism from people and lack of trust in such systems has caused relatively slow growth of technology acceptance. This study model aims to examine the disposition, perceived risks, website dimensions and e-trust, and online self-efficacy influence an individual's perception of the digitalization of the economy. For the purpose of the study, questionnaires were issued in various social platforms like Facebook and twitter to collect data and a total of 3000 respondents were sampled out of a group of millions. There was a significant difference in the results obtained from educated and uneducated individuals. Also, the male gender had an upper hand in computer skills than females. The results of the data collection method would be used to explain the effects of e-trust and the risks perceived for further research.
\end{abstract}

Keywords: websites dimensions and e-trust, disposition, perceived risks, and online self-efficacy.

DOI: $10.7176 / \mathrm{IKM} / 9-3-10$

Publication date:March $31^{\text {st }} 2019$

\section{Introduction}

The fact that breaches of Internet security systems are often reported means that there is a danger that potential users will be reluctant to engage in e-commerce because of fears of been compromised. According to a recent Commerce Net report (Barriers to Electronic Commerce 2000), security and trust are the dominant issues of concern to consumers. These issues appear to be the main barriers to consumer involvement in e-commerce. In addition, since e-commerce provides an alternative method for value exchange over the Internet, it is inevitable that financial risk becomes an issue of concern to e-commerce consumers. This research aims at explaining consumer risk perceptions concerning e-commerce in Ivory Coast and China. In this study, data collection procedure is guided by research questions and hypotheses through statistical analysis. The research findings and limitations are further discussed in the paper. 


\section{Background of the Study}

Technology trust is based on technical safeguards, protective measures, and control mechanisms that aim to provide reliable transactions from timely, accurate, and complete data transmission (Cassell, 2000). Generally, ecommerce and modern technology have played a very important role in the improvements of living standards as said Daniel \& Jonathan, 2013. This is because of their anonymity and speed, hence more reliable than the traditional methods. Consequently, this has strengthened many commercial institutions and the competition around them. E-commerce refers to business transactions that is conducted over the internet evoke by Acheampong et.al, 2017. These modern technologies are crucial to both producers and consumers and hence their trust is very fundamental because it is a requirement for transactional procedures and transparency. Therefore, trust is crucial for clients to feel secure since it may hamper the development of e-commerce (Jeong, 2013). Therefore, there is a continued need to conduct numerous researches concerning the risks perceived by the consumers when accepting and using these e-products to conduct their routine transactions. Notably, individuals have their own opinions concerning securities of electronic systems which vary according their perceptions.

Perceived risks is one of the factors that deceive an individual when triggered by such emotions of loss from the environment or advise from a large group (Weber and C.K. Hsee, 1998). Such emotions can be brought about by producer-consumer conflicts causing transactional uncertainties. Online payment has been contributing significantly in the economic development and this has brought about fraud in some cases. Concerning consumers' perceptions, different organizations have diverse ways of conducting e-commerce. In some cases, consumers have been being assure of high-quality products while transacting online only to receive counterfeits when delivered, staining the consumers' trust in such firms (M. A. Radwan, 2010). The exaggerated price of commodities in developing countries like Ivory Coast have made it difficult for a larger portion of the population to access internet services like e-banking. Electronic gadgets such computers and smartphones are highly price, hence only the a few individuals with a high income can purchase them and this hampers technological advancement. This study elaborates factors that limit economic growth of a country such as ignorance of conservative and unlearned population to conduct economic activities.

Notably, Ivory Coast has been experiencing significant technological improvements resulting into an increased internet consumption to conduct economic activities. For example, e-payments and mobile phone transactions have been adopted as an alternative means of conducting e-commerce. However, there are certain factors that limit the technological growth in Ivory coast. These factors include perceptional risks in which consumers lack the fundamental trust in the electronic systems.

\section{Statement of the Problem}

Technology is changing both global transactions and communications as it enables people to work and communicate beyond their conventional offices and meeting places. This has led to the decrease in the constraints of geographical distance and emergence of new avenues for progressive and dynamic communication between people. Furthermore, the implementation and use of information technology is changing the way people are teaching and learning.

Due to the rapid proliferation of the internet, e-commerce has become a common global phenomenon. Trading over the internet is rapidly becoming the new business reality and people are becoming accustomed to purchasing goods and services from foreign countries. E-commerce has been considered as a great opportunity for developing countries to take advantages of opportunities in the global market. It plays a fundamental role in helping developing nations to maximize revenue from trade because it requires less physical infrastructure which translates to low operational costs, thus high profits (Özdemir, 2013). Besides, it allows for better and quicker customer service.

Despite the many advantages of e-commerce, most developing countries are still not able to realize the full benefits due to many factors that act as barriers. Technology developers and industries have identified notable differences between developing technology and its usage because the lack of technology acceptance by users would result in great losses for these industries. This study therefore seeks to fill a research gap by investigating the influence of individual perception factors on their acceptance of e-commerce technology between Ivory coast and China. This comparison is important because these countries are at different technological and different economic levels. This will be done by use of the technology acceptance model (TAM) developed by Fred Davis in 1986 to explain the phenomena regarding behavior and beliefs in usage of 
technology (Taherdoost, 2018). The model attempts to show how users can accept and use technology to carry out certain tasks as opposed to traditional methods.

\title{
Objectives of the Study
}

The general objective of this study is to investigate the factors affecting technology acceptance among the citizens of Ivory Coast and China. The specific objectives of the study are:

i. To determine the effect of disposition on technology acceptance among the citizens of Ivory Coast and China.

ii. To determine the role of perceived risks on technology acceptance among the citizens of Ivory Coast and China.

iii. To find out how website dimensions and e-trust affect technology acceptance among the citizens of Ivory Coast and China.

iv. To investigate the influence of self-efficacy on technology acceptance among the citizens of Ivory Coast and China.

\author{
Research Hypothesis \\ $\mathrm{H}_{(\mathrm{a})}$ - Disposition has a significant effect on technology acceptance \\ $\mathrm{H}_{(\mathrm{b})}$ - Perceived risk has a significant effect on technology acceptance \\ $\mathrm{H}_{(\mathrm{c})}$ - Website dimensions and e-trust have a significant effect on technology acceptance \\ $\mathrm{H}_{(\mathrm{d})}$ - Self-efficacy has a significant effect on technology acceptance
}

\section{Significance of the Study}

The findings of this study will be important to the population of developing countries since e-commerce can help developing economies gain more from trade. The great reduction in physical infrastructure requirements and better and faster customer service justifies the need for implementation of e-commerce and its associated technology. Thus, organizations that apply the recommended approach will be guided on what should be emphasized in conducting trade to improve their profits and better service delivery. Furthermore, this research will guide policy makers on areas to be implemented to stimulate economic development through technological advancements. For academicians, this study will help to uncover critical areas in consumer behavior that many researchers were unable to explore.

\section{Scope and Limitations of the Study}

This study focused on respondents who could be reached through social media. It relied on those that were willing to participate in the study. Although there are many issues affecting technology acceptance, this study only focused on the selected technology acceptance factors such as disposition, perceived risk, website dimensions and self-efficacy. While carrying out the study, a lot of challenges were encountered. For example, some people were dishonest while answering the questions, hence affecting the overall result of the research. Furthermore, during the study, it was very difficult to reach some groups of people within the population for they were remotely located and had either no access or limited access to electronic devices. It was also very difficult to get tangible results from the uneducated population because they were only able to understand their local dialect hence language barrier.

\section{Assumptions of the Study}

The study assumed that the sample was representative of the whole population of the study and that the findings could be generalized. Besides, it assumed that the respondents would give honest and factual responses relevant to the study. The study further assumed that the respondents being interviewed for the purpose of the 
study were willing to respond to the questions and that the technology acceptance factors in question affected the respondents' acceptance of technology in the theoretically stipulated ways. The final assumption was that the data gathered could be empirically observed and assessed.

\section{Literature Review}

The Technology Acceptance Model (TAM) was originally introduced and studied as a means of understanding how users adopt and use new technology by evaluating the factors that influenced the decision to accept a new technology (Davis FD, 1989). TAM is based on the belief "that perceived ease of use and usefulness can predict attitudes toward technology" (Lederer, 2000). Perceived usefulness of a technology and perceived ease of use of a technology combine to create an attitude about the technology, influencing decisions of whether to adopt the technology. Perceived ease of use and perceived usefulness are shaped by external factors unique to the situation, while the behavioral decisions ultimately dictate whether and how a technology is used (Davis F., 1989).

Since its introduction, TAM has been tested in many studies and has been used to evaluate numerous different technologies, including email, voice mail, and many others (Dasgupta, 2002; Gefen, 2000; Straub, 1997). Some recent studies of TAM have extended the application of the model to areas beyond a single technology, such as the study of online educational settings or the World Wide Web (Dishaw, 1999; Saadé, 2005; D. F. D. Venkatesh, 2000).

TAM explains the general determinants of computer acceptance that lead to explaining users' behaviors across a broad range of end-user computing technologies and user populations. The basic TAM model included and tested two specific beliefs: Perceived Usefulness (PU) and Perceived Ease of Use (PEU). Perceived Usefulness is defined as the potential user's subjective likelihood that the use of a certain system such as single platform epayment system, will improve his/her action and Perceived Ease of Use refers to the degree to which the potential user expects the target system to be effortless. The conceptual framework for this study is derived from the technology acceptance model by (Kock, 2017) and is illustrated in the figure below.

TAM displays how users accept and use new technology. The model describes the factors that influence users' decisions about how and when they will use new technology, particularly. Perceived usefulness was defined by Davis (1989) as "the degree to which a person believes that using a particular system would enhance his or her job performance". Perceived ease-of-use is defined as "the degree to which a person believes that using a particular system would be free from effort" (Davis, 1989). TAM has been continuously studied and expanded. Several researchers have replicated Davis's study to provide evidence on the relationships between usefulness, ease of use and system use. Ease of use and usefulness are important factors in evaluating online service quality (Rod et al., 2009). TAM is a valuable tool in forecasting satisfaction, improving customer service and improving service quality. TAM model hardly needs an introduction as it is well established in information system research. Introduced by Davis et al. (1989) and Davis (1989), the model states that perceived usefulness and perceived ease of use jointly determine the user's behavioral intention to use the system. The model is an adaptation of the theory of reasoned action (L. Ajzen, \& Fishbein, M, 1980) and most famous for its parsimony and explanatory power. TAM has been extended in many directions: examples include antecedents of perceived ease of use (Venkatesh, 2000) and perceived usefulness (D. F. D. Venkatesh, 2000). The model has also been refined with moderating influences such as age and gender (Venkatesh V., 2003) and applied successfully in a diverse range of settings, including e-government. The model spawned a foundation of literature and now enjoys almost iconic status.

Technology advances that have resulted and will result into number of complicated advances could not have been imagined a decade ago (Bitner, 2010). Hence customer expectations from these innovative technologydriven services do not fit the early models of service expectations. Attracting large volumes of customers' needs a consistent delivery of high-level service quality. For investigating e-service adoption, the theory of planned behavior is significant as it relates the causal link between Internet self-efficacy and e-service adoption (I. Ajzen, 2002). Prior research provides evidence that attitudes have a significant impact on intentions in the context of IT adoption and usage (Agarwal, 1999; Chau, 2001; Taylor, 1995). Loyalty towards the online services arrives as a new, important variable in user acceptance research. (Swaid, 2007) establish the concept of e-service quality and their influence on intention to use and online loyalty. While theory of reasoned action and theory of planned behavior have the capability to explore the system usage by incorporating subjective norms and perceived behavioral controls with attitudes toward using technology, TAM is more appropriate to be applied in online 
contexts for several advantages. First, TAM is specific on information system usage for applying the concepts of ease of use and usefulness. Besides, TAM is more parsimonious. Furthermore, TAM is stronger in various information system applications.

Perceived ease of use (PEOU)

According to Davis (1989) perceived ease of use refers to "the degree to which a person believes that using a particular system would be free of effort». The most significant factor on adoption Internet Banking is ease of use.(Padachi, 2008; Safeena, 2010), (Jahangir, 2008; Z. Liao, \& Wong, W. K. (2007), 2007) stated that perceived ease of use has a strong and positive influence on customers intention to adopt and use internet banking.

Perceived usefulness (PU)

According to the Davis (1989) and Davis et al. (1989), perceived usefulness is "the degree to which a person believes that using a particular system would enhance his or her job performance". Perceived usefulness is defined as "the individual's perception that using the new technology will enhance or improve her/his performance" (Davis,1993). In Addition, (Laforet, 2005) defined the term perceived usefulness as "the subjective probability that using the technology would improve the way a user could complete". Several studies showed that perceived usefulness influence customer interactions with internet banking, which effect the adoption of e-banking services (Amin, June 18, 2007; Jahangir, 2008; Z. Liao, \& Wong, W. K.)

Attitudes Toward use (ATU)

Lancaster (1996) has shown that attitude is the driver of consumer utility or attributes. (Triandis, 1979) portrayed attitude as the positive or negative behavior of an individual with respect to adaptation to innovation. For Doob the attitude is the "implicit response generating drive considered socially significant in the society of individuals". (Chen, 2002) referred to it as "a disposition to evaluate certain objects, actions and situations in certain ways". These definitions show that attitude is an implicit response with a driving force that occurs in the individual in response to stimulus patterns and affects subsequent manifest responses. Recently, (Pikkarainen, 2004) defined attitude as the basis of compatibility, which includes, for example, the preference for self-service, technology and lifestyle. Davis also found that the attitude was at best a partial mediator of the effect of perceived utility on intent to use, and that it adds little chance explanatory power to the intention of using it. an individual to use a particular information system. People who thought using a new technology would lead to more positive results, also tend to be more supportive of them. According to Ajzen and Fishbein 1975, this attitude is the positive or negative feeling associated with adopting a specific behavior. They believed that an individual would have a favorable attitude towards a given behavior if he / she felt that the performance of this behavior would lead to generally positive results. On the other hand, if the individual thinks that the behavior will have mainly negative consequences, he / she will adopt a negative attitude towards it (Myktyin, 2003). TAM is based on the theory of reasoned action (TRA), according to which beliefs influence intentions and intentions influence everyone's actions Ajzen, 2002. According to TAM, PU and PEU influence the intention of each user to use the system, which influences the behavioral intention to use a system (ITU).

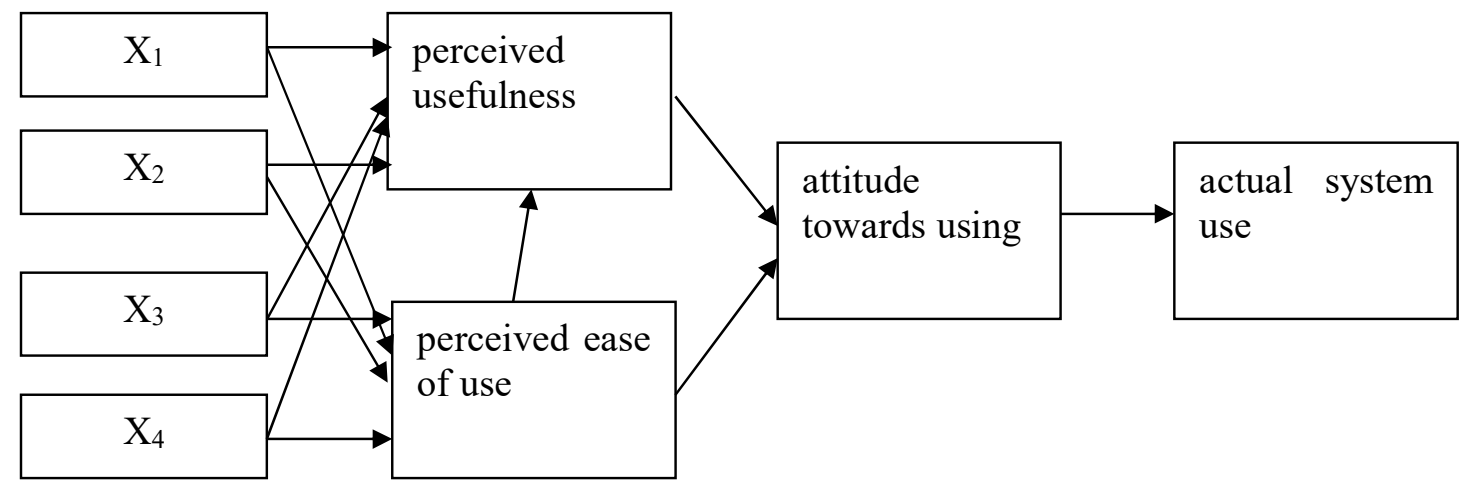

Independent variables

Dependent variables

Where; $\mathrm{X}_{1}=$ Disposition, $\mathrm{X}_{2}=$ Perceived Risks, $\mathrm{X}_{3}=$ Website dimensions and e-trust and $\mathrm{X}_{4}=$ Self-efficacy. 
From the above figure the independent variables namely disposition, perceived risks, website dimensions and e-trust and self-efficacy shape an individual's perception of usefulness and ease of use. An individual's perception of the ease of use directly affects their perception of usefulness. An individual's perception of usefulness and ease of use each affect the individual's attitude towards use of the system which in turn determines their actual use of the system.

\section{Methodology}

Research Design

This research employed quantitative methods. It focuses on gathering numerical data and generalizing it across groups of people or to explain a particular phenomenon. This research also adopted a causal research design as it was to determine whether technology acceptance prediction factors affected individual acceptance of ecommerce technology

Study Population

The target population for this study was the entire population of Ivory Coast and China who were aged between 18 and 80 years. However, since this research focused on use of the internet and collected data using the social media, the accessible population was the population that had access to the internet and were active on social media. According to IWS (2018) Ivory Coast, had a population of 24,9 million people and (6,538,355 Internet users in Dec/2017) 26.3\% of the population being internet users in December 2017. while China has 802 million people who actively use internet, which is more than $57 \%$ of the entire population (McCarthy, 2018). This gives an accessible population of approximately 10.1 million people. According to researchers any study population of over 50,000 is considered as an infinite population.

\section{Sample Size}

It is difficult to collect information from the whole population. This is why researchers have to rely on sampling techniques. A sample size must however be representative of the whole population so that the researcher is allowed to make inferences or generalization from the sample statistics to the population understudied. To determine an accurate sample size that yield research results that reflect the study population this study.

\section{Sampling Methods and Procedures}

This research used $30 \%$ of the sample population to select the respondents of the study as the methodology allows the target population an equal chance to participate in the study. The sample was dived into two main groups namely the group that have participated in the e-commerce be it once or more and the group that have never made any online transaction in their lifetime hence the questions of each groups would differ significantly because of their first reply.

\section{Data Collection Instruments and Procedures}

The data was collected through a closed ended questionnaire based on a 5-point Likert scale. This means that the questions presented could be answered by simple one-word answer (i.e. either a yes or no; or one of the five choices in the five-point Likert scale). For the purpose of the study questionnaires were issued in various social platforms like Facebook and twitter as one form of data collection.

Data Analysis and Presentation Methods

Data was analyzed statistically using SPSS version 24. The study was regressed based on the following econometric regression model; 
Table 1: Different factors affecting perceptional risks, website dimensions and e-trust in China and Ivory Coast.

\begin{tabular}{|l|l|l|l|}
\hline Factors & Figures & Findings & Remarks \\
\hline Age & $\begin{array}{l}\text { Total respondents were } \\
3000.2000 \text { are below } \\
\text { the ages of 30 years, } \\
\text { while } 1000 \text { were above } \\
\text { thirty years. }\end{array}$ & $\begin{array}{l}\text { The } 2000 \text { responded to have } \\
\text { a used the internet to carry } \\
\text { out various transactions, } \\
\text { while the other } 1000 \text { very } \\
\text { few numbers of them have } \\
\text { ever used the internet to } \\
\text { carry out transactions. }\end{array}$ & $\begin{array}{l}\text { The huge numbers of } \\
\text { respondents were mainly the } \\
\text { people under the age of } \\
\text { thirty because they widely } \\
\text { use social networks. }\end{array}$ \\
\hline Gender & $\begin{array}{l}\text { The numbers of female } \\
\text { respondents were equal } \\
\text { to their male } \\
\text { counterparts which is } \\
\text { 1500 each. }\end{array}$ & $\begin{array}{l}\text { There was no difference in } \\
\text { their views on the online } \\
\text { transactions. }\end{array}$ & $\begin{array}{l}\text { Both the genders are equally } \\
\text { active in the economic } \\
\text { growth of the country }\end{array}$ \\
\hline $\begin{array}{l}\text { Level of } \\
\text { education }\end{array}$ & $\begin{array}{l}\text { The number of learned } \\
\text { individuals was slightly } \\
\text { higher than the } \\
\text { unlearned individuals } \\
\text { the figures being } 1800 \\
\text { and } 1200 \text { respectively. }\end{array}$ & $\begin{array}{l}\text { The learned grouped have } \\
\text { positively responded and } \\
\text { have carried out a lot of } \\
\text { online transactions as } \\
\text { opposed to the lower level of } \\
\text { education individuals. }\end{array}$ & $\begin{array}{l}\text { The learned respondents } \\
\text { were quite many because of } \\
\text { their awareness of } \\
\text { technology. }\end{array}$ \\
\hline $\begin{array}{l}\text { Experience } \\
\text { in e- } \\
\text { commerce }\end{array}$ & $\begin{array}{l}\text { Those who have used } \\
\text { the internet were } 2500 \\
\text { while those that haven't } \\
\text { used it were } 500 .\end{array}$ & $\begin{array}{l}\text { The grouped that haven't } \\
\text { used the internet posed many } \\
\text { challenges affecting their } \\
\text { lack of online transaction } \\
\text { some included like lack of } \\
\text { computers. }\end{array}$ & $\begin{array}{l}\text { The countries are rapidly } \\
\text { growing in terms of } \\
\text { technology hence many } \\
\text { people access the internet } \\
\text { services. }\end{array}$ \\
$\begin{array}{l}\text { hespondents while the } \\
\text { lower income level had } \\
1300 .\end{array}$ & $\begin{array}{l}\text { low-income earners was as a } \\
\text { result of fear of losing the } \\
\text { little money they had over } \\
\text { frauds. }\end{array}$ & $\begin{array}{l}\text { This is mainly because the } \\
\text { electronic } \\
\text { telecommunication devices } \\
\text { are very expensive hence a } \\
\text { lot of people cannot save up. }\end{array}$ \\
\hline
\end{tabular}




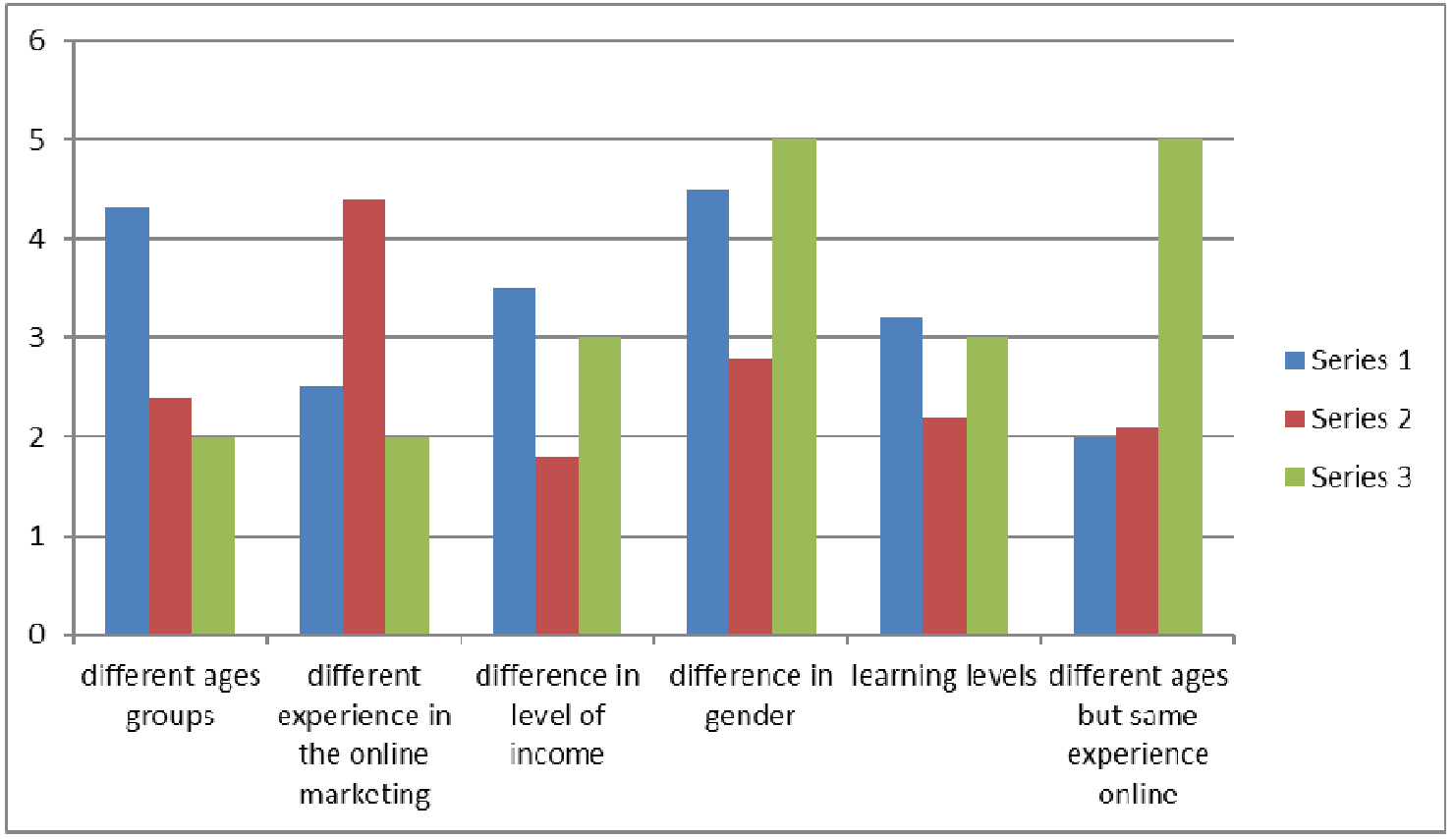

Fig one. Each category of respondents and their numbers.

Table 4.1: Chi-Square Tests

\begin{tabular}{|l|r|r|r|}
\hline & \multicolumn{1}{|c|}{ Value } & df & Asymp. Sig. (2-sided) \\
\hline Pearson Chi-Square & $12.145^{\mathrm{a}}$ & 4 & .016 \\
Likelihood Ratio & 12.155 & 4 & .016 \\
Linear-by-Linear Association & .000 & 1 & .988 \\
N of Valid Cases & 2999 & & \\
\hline
\end{tabular}

a. 0 cells $(0.0 \%)$ have expected count less than 5 . The minimum expected count is 284.64 .

Table 4.2: Symmetric Measures

\begin{tabular}{|ll|r|r|}
\hline & & Value & Approx. Sig. \\
\hline \multirow{2}{*}{ Nominal by Nominal } & Phi & .064 & .016 \\
& Cramer's V & .064 & .016 \\
N of Valid Cases & & 2999 & \\
\hline
\end{tabular}

a. Not assuming the null hypothesis.

b. Using the asymptotic standard error assuming the null hypothesis. 


\section{Gender * I have never transacted online because I don't have a computer? * Education level}

\section{Crosstabulation}

Education level: Total

Count

\begin{tabular}{|ll|r|r|r|r|r|r|}
\hline & \multicolumn{6}{|c|}{ I have never transacted online because I don't have a computer? } & \multirow{2}{*}{ Total } \\
\cline { 3 - 8 } & & Strongly Agree & Agree & Neutral & Disagree & Strongly disagree & \\
\hline \multirow{3}{*}{ Gender } & Male & 280 & 311 & 319 & 301 & 301 & 1512 \\
& Female & 313 & 304 & 330 & 276 & 264 & 1487 \\
Total & & 593 & 615 & 649 & 577 & 565 & 2999 \\
\hline
\end{tabular}

Table 4.4: Symmetric Measures

\begin{tabular}{|c|c|c|c|c|}
\hline Education level & & & Value & Approx. Sig. \\
\hline \multirow[t]{2}{*}{ Primary } & Nominal by Nominal & $\begin{array}{l}\text { Phi } \\
\text { Cramer's V }\end{array}$ & $\begin{array}{l}.191 \\
.191\end{array}$ & $\begin{array}{l}.002 \\
.002\end{array}$ \\
\hline & $\mathrm{N}$ of Valid Cases & & 479 & \\
\hline \multirow{3}{*}{ Secondary } & \multirow{2}{*}{ Nominal by Nominal } & Phi & .062 & .747 \\
\hline & & Cramer's V & .062 & .747 \\
\hline & $\mathrm{N}$ of Valid Cases & & 507 & \\
\hline \multirow{3}{*}{ Tertiary/Certificate/Diploma } & \multirow{2}{*}{ Nominal by Nominal } & Phi & .048 & .879 \\
\hline & & Cramer's V & .048 & .879 \\
\hline & $\mathrm{N}$ of Valid Cases & & 511 & \\
\hline \multirow{3}{*}{ Degree } & \multirow{2}{*}{ Nominal by Nominal } & Phi & .043 & .926 \\
\hline & & Cramer's V & .043 & .926 \\
\hline & $\mathrm{N}$ of Valid Cases & & 477 & \\
\hline \multirow{3}{*}{ Masters } & \multirow{2}{*}{ Nominal by Nominal } & Phi & .080 & .509 \\
\hline & & Cramer's V & .080 & .509 \\
\hline & $\mathrm{N}$ of Valid Cases & & 518 & \\
\hline \multirow{3}{*}{$\mathrm{PhD}$} & \multirow{2}{*}{ Nominal by Nominal } & Phi & .061 & .756 \\
\hline & & Cramer's V & .061 & .756 \\
\hline & $\mathrm{N}$ of Valid Cases & & 507 & \\
\hline \multirow{3}{*}{ Total } & \multirow{2}{*}{ Nominal by Nominal } & Phi & .042 & .249 \\
\hline & & Cramer's V & .042 & .249 \\
\hline & $\mathrm{N}$ of Valid Cases & & 2999 & \\
\hline
\end{tabular}

a. Not assuming the null hypothesis.

b. Using the asymptotic standard error assuming the null hypothesis. 
Table 4.5 Online payment: Male vs Female

\begin{tabular}{|c|c|c|c|c|c|c|c|}
\hline & & \multicolumn{5}{|c|}{$\begin{array}{l}\text { I don't trust that my payment credentials won't be badly used } \\
\text { after the transaction has taken place. }\end{array}$} & \multirow[t]{2}{*}{ Total } \\
\hline & & $\begin{array}{l}\text { Strongly } \\
\text { Agree }\end{array}$ & Agree & Neutral & Disagree & $\begin{array}{l}\text { Strongly } \\
\text { disagree }\end{array}$ & \\
\hline \multirow{2}{*}{ Gender } & Male & 310 & 308 & 299 & 311 & 284 & 1512 \\
\hline & Female & 308 & 296 & 318 & 289 & 276 & 1487 \\
\hline Total & & 618 & 604 & 617 & 600 & 560 & 2999 \\
\hline
\end{tabular}

Table 4.6: Chi-Square Tests

\begin{tabular}{|c|c|c|c|c|}
\hline Education level & & Value & $\mathrm{df}$ & Asymp. Sig. (2-sided) \\
\hline \multirow{4}{*}{ Primary } & Pearson Chi-Square & $3.043^{\mathrm{b}}$ & 4 & .551 \\
\hline & Likelihood Ratio & 3.050 & 4 & .550 \\
\hline & Linear-by-Linear Association & .023 & 1 & .879 \\
\hline & $\mathrm{N}$ of Valid Cases & 479 & & \\
\hline \multirow{4}{*}{ Secondary } & Pearson Chi-Square & $.453^{\mathrm{c}}$ & 4 & .978 \\
\hline & Likelihood Ratio & .452 & 4 & .978 \\
\hline & Linear-by-Linear Association & .074 & 1 & .786 \\
\hline & $\mathrm{N}$ of Valid Cases & 507 & & \\
\hline \multirow{4}{*}{ Tertiary/Certificate/Diploma } & Pearson Chi-Square & $2.308^{\mathrm{d}}$ & 4 & .679 \\
\hline & Likelihood Ratio & 2.315 & 4 & .678 \\
\hline & Linear-by-Linear Association & .398 & 1 & .528 \\
\hline & $\mathrm{N}$ of Valid Cases & 511 & & \\
\hline \multirow{4}{*}{ Degree } & Pearson Chi-Square & $1.147^{\mathrm{e}}$ & 4 & .887 \\
\hline & Likelihood Ratio & 1.147 & 4 & .887 \\
\hline & Linear-by-Linear Association & .063 & 1 & .802 \\
\hline & $\mathrm{N}$ of Valid Cases & 477 & & \\
\hline \multirow{4}{*}{ Masters } & Pearson Chi-Square & $10.538^{\mathrm{f}}$ & 4 & .032 \\
\hline & Likelihood Ratio & 10.615 & 4 & .031 \\
\hline & Linear-by-Linear Association & 2.873 & 1 & .090 \\
\hline & $\mathrm{N}$ of Valid Cases & 518 & & \\
\hline \multirow{4}{*}{$\mathrm{PhD}$} & Pearson Chi-Square & $11.166^{\mathrm{g}}$ & 4 & .025 \\
\hline & Likelihood Ratio & 11.210 & 4 & .024 \\
\hline & Linear-by-Linear Association & 5.996 & 1 & .014 \\
\hline & $\mathrm{N}$ of Valid Cases & 507 & & \\
\hline \multirow{4}{*}{ Total } & Pearson Chi-Square & $1.543^{\mathrm{a}}$ & 4 & .819 \\
\hline & Likelihood Ratio & 1.543 & 4 & .819 \\
\hline & Linear-by-Linear Association & .089 & 1 & .765 \\
\hline & $\mathrm{N}$ of Valid Cases & 2999 & & \\
\hline
\end{tabular}

a. 0 cells $(0.0 \%)$ have expected count less than 5 . The minimum expected count is 277.67 .

b. 0 cells $(0.0 \%)$ have expected count less than 5 . The minimum expected count is 35.62 .

c. 0 cells $(0.0 \%)$ have expected count less than 5 . The minimum expected count is 44.33 .

d. 0 cells $(0.0 \%)$ have expected count less than 5 . The minimum expected count is 43.37 .

e. 0 cells $(0.0 \%)$ have expected count less than 5 . The minimum expected count is 39.67.

f. 0 cells $(0.0 \%)$ have expected count less than 5 . The minimum expected count is 48.00 .

g. 0 cells $(0.0 \%)$ have expected count less than 5 . The minimum expected count is 43.97 . 
Table 4.5b: Symmetric Measures

\begin{tabular}{|c|c|c|c|c|}
\hline Education level & & & Value & Approx. Sig. \\
\hline \multirow{3}{*}{ Primary } & \multirow{2}{*}{ Nominal by Nominal } & Phi & .080 & .551 \\
\hline & & Cramer's V & .080 & .551 \\
\hline & $\mathrm{N}$ of Valid Cases & & 479 & \\
\hline \multirow[b]{2}{*}{ Secondary } & \multirow{2}{*}{ Nominal by Nominal } & Phi & .030 & .978 \\
\hline & & Cramer's V & .030 & .978 \\
\hline \multirow[b]{2}{*}{ Tertiary/Certificate/Diploma } & \multirow{2}{*}{ Nominal by Nominal } & Phi & .067 & .679 \\
\hline & & Cramer's V & .067 & .679 \\
\hline \multirow{3}{*}{ Degree } & \multirow{2}{*}{ Nominal by Nominal } & Phi & $\begin{array}{l}511 \\
.049\end{array}$ & .887 \\
\hline & & Cramer's V & .049 & .887 \\
\hline & $\mathrm{N}$ of Valid Cases & & 477 & \\
\hline \multirow[b]{2}{*}{ Masters } & \multirow{2}{*}{ Nominal by Nominal } & Phi & .143 & .032 \\
\hline & & Cramer's V & .143 & .032 \\
\hline \multirow{3}{*}{$\mathrm{PhD}$} & \multirow{2}{*}{ Nominal by Nominal } & & $\begin{array}{l}518 \\
.148\end{array}$ & .025 \\
\hline & & Cramer's V & .148 & .025 \\
\hline & $\mathrm{N}$ of Valid Cases & & 507 & \\
\hline \multirow{3}{*}{ Total } & \multirow{2}{*}{ Nominal by Nominal } & Phi & .023 & .819 \\
\hline & & Cramer's V & .023 & .819 \\
\hline & $\mathrm{N}$ of Valid Cases & & 2999 & \\
\hline
\end{tabular}

a. Not assuming the null hypothesis.

c. Using the asymptotic standard error assuming the null hypothesis. 
Table 4.6: Chi-Square Tests

\begin{tabular}{|c|c|c|c|c|}
\hline \multicolumn{2}{|c|}{$\begin{array}{l}\text { I don't transact more on the internet because I fear sharing personal details in } \\
\text { the fear that there is no privacy in the web }\end{array}$} & Value & df & $\begin{array}{l}\text { Asymp. Sig. (2- } \\
\text { sided) }\end{array}$ \\
\hline \multirow{5}{*}{ Strongly Agree } & Pearson Chi-Square & $21.962^{b}$ & 16 & .144 \\
\hline & Likelihood Ratio & 22.515 & 16 & .127 \\
\hline & Linear-by-Linear Association & .985 & 1 & .321 \\
\hline & $\mathrm{N}$ of Valid Cases & 635 & & \\
\hline & Pearson Chi-Square & $20.124^{c}$ & 16 & .215 \\
\hline \multirow{3}{*}{ Agree } & Likelihood Ratio & 20.381 & 16 & .204 \\
\hline & Linear-by-Linear Association & 4.489 & 1 & .034 \\
\hline & $\mathrm{N}$ of Valid Cases & 594 & & \\
\hline \multirow{4}{*}{ Neutral } & Pearson Chi-Square & $13.520^{\mathrm{d}}$ & 16 & .634 \\
\hline & Likelihood Ratio & 13.592 & 16 & .629 \\
\hline & Linear-by-Linear Association & 2.579 & 1 & .108 \\
\hline & $\mathrm{N}$ of Valid Cases & 571 & & \\
\hline \multirow{4}{*}{ Disagree } & Pearson Chi-Square & $17.570^{\mathrm{e}}$ & 16 & .350 \\
\hline & Likelihood Ratio & 17.364 & 16 & .362 \\
\hline & Linear-by-Linear Association & .487 & 1 & .485 \\
\hline & $\mathrm{N}$ of Valid Cases & 586 & & \\
\hline \multirow{4}{*}{ Strongly disagree } & Pearson Chi-Square & $14.324^{\mathrm{f}}$ & 16 & .575 \\
\hline & Likelihood Ratio & 14.239 & 16 & .581 \\
\hline & Linear-by-Linear Association & .449 & 1 & .503 \\
\hline & $\mathrm{N}$ of Valid Cases & 613 & & \\
\hline \multirow{4}{*}{ Total } & Pearson Chi-Square & $21.623^{\mathrm{a}}$ & 16 & .156 \\
\hline & Likelihood Ratio & 21.949 & 16 & .145 \\
\hline & Linear-by-Linear Association & .354 & 1 & .552 \\
\hline & $\mathrm{N}$ of Valid Cases & 2999 & & \\
\hline
\end{tabular}

a. 0 cells $(0.0 \%)$ have expected count less than 5 . The minimum expected count is 105.50 .

b. 0 cells $(0.0 \%)$ have expected count less than 5 . The minimum expected count is 20.83 .

c. 0 cells $(0.0 \%)$ have expected count less than 5 . The minimum expected count is 20.37 .

d. 0 cells $(0.0 \%)$ have expected count less than 5 . The minimum expected count is 19.07.

e. 0 cells $(0.0 \%)$ have expected count less than 5 . The minimum expected count is 19.71 .

f. 0 cells $(0.0 \%)$ have expected count less than 5 . The minimum expected count is 21.76 .

Table 4.7: Paired Samples Correlations

\begin{tabular}{|c|c|c|c|c|}
\hline & & $\mathrm{N}$ & Correlation & Sig. \\
\hline $\begin{array}{l}\text { Pair } \\
1\end{array}$ & $\begin{array}{l}\text { Education level \& I have never transacted online because the transaction will } \\
\text { all be just as scam and never get results. }\end{array}$ & 2999 & .009 & .610 \\
\hline $\begin{array}{l}\text { Pair } \\
2\end{array}$ & $\begin{array}{l}\text { I have never transacted online because the transaction will all be just as scam } \\
\text { and never get results. \& I believe that I will get the quality I expected? }\end{array}$ & 2999 & .013 & .467 \\
\hline
\end{tabular}


Table 4.8: Age and Risk, Chi-Square Tests

\begin{tabular}{|l|r|r|r|}
\hline & Value & df & Asymp. Sig. (2-sided) \\
\hline Pearson Chi-Square & $12.570^{\mathrm{a}}$ & 8 & .128 \\
Likelihood Ratio & 12.568 & 8 & .128 \\
Linear-by-Linear Association & 3.900 & 1 & .048 \\
N of Valid Cases & 2999 & & \\
\hline
\end{tabular}

a. 0 cells $(0.0 \%)$ have expected count less than 5 . The minimum expected count is 182.06 .

Table 4.9: risk education and age, Chi-Square Tests

\begin{tabular}{|c|c|c|c|c|}
\hline Education level & & Value & df & Asymp. Sig. (2-sided) \\
\hline \multirow{4}{*}[10-20]{} & Pearson Chi-Square & $2.248^{\mathrm{b}}$ & 8 & .972 \\
\hline & Likelihood Ratio & 2.248 & 8 & .972 \\
\hline & Linear-by-Linear Association & .072 & 1 & .788 \\
\hline & $\mathrm{N}$ of Valid Cases & 479 & & \\
\hline \multirow{3}{*}[30-40]{} & Pearson Chi-Square & $19.640^{\mathrm{c}}$ & 8 & .012 \\
\hline & Likelihood Ratio & 19.702 & 8 & .012 \\
\hline & Linear-by-Linear Association & 3.838 & 1 & .050 \\
\hline \multirow{5}{*}[50-60]{} & $\mathrm{N}$ of Valid Cases & 507 & & \\
\hline & Pearson Chi-Square & $17.728^{\mathrm{d}}$ & 8 & .023 \\
\hline & Likelihood Ratio & 18.197 & 8 & .020 \\
\hline & Linear-by-Linear Association & 1.746 & 1 & .186 \\
\hline & $\mathrm{N}$ of Valid Cases & 511 & & \\
\hline \multirow{3}{*}{4} & Pearson Chi-Square & $9.495^{\mathrm{e}}$ & 8 & .302 \\
\hline & Likelihood Ratio & 9.474 & 8 & .304 \\
\hline & Linear-by-Linear Association & 1.966 & 1 & .161 \\
\hline \multirow{4}{*}{5} & $\mathrm{~N}$ of Valid Cases & 477 & & \\
\hline & Pearson Chi-Square & $8.259^{f}$ & 8 & .409 \\
\hline & Likelihood Ratio & 8.360 & 8 & .399 \\
\hline & Linear-by-Linear Association & 1.134 & 1 & .287 \\
\hline \multirow{5}{*}{6} & $\mathrm{~N}$ of Valid Cases & 518 & & \\
\hline & Pearson Chi-Square & $9.989^{\mathrm{g}}$ & 8 & .266 \\
\hline & Likelihood Ratio & 10.239 & 8 & .249 \\
\hline & Linear-by-Linear Association & 3.376 & 1 & .066 \\
\hline & $\mathrm{N}$ of Valid Cases & 507 & & \\
\hline \multirow{4}{*}{ Total } & Pearson Chi-Square & $12.570^{\mathrm{a}}$ & 8 & .128 \\
\hline & Likelihood Ratio & 12.568 & 8 & .128 \\
\hline & Linear-by-Linear Association & 3.900 & 1 & .048 \\
\hline & $\mathrm{N}$ of Valid Cases & 2999 & & \\
\hline
\end{tabular}

a. 0 cells $(0.0 \%)$ have expected count less than 5 . The minimum expected count is 182.06 .

b. 0 cells $(0.0 \%)$ have expected count less than 5 . The minimum expected count is 23.45 . 
c. 0 cells $(0.0 \%)$ have expected count less than 5 . The minimum expected count is 29.62 .

d. 0 cells $(0.0 \%)$ have expected count less than 5 . The minimum expected count is 28.39 .

e. 0 cells $(0.0 \%)$ have expected count less than 5 . The minimum expected count is 26.62 .

f. 0 cells $(0.0 \%)$ have expected count less than 5 . The minimum expected count is 31.32 .

g. 0 cells $(0.0 \%)$ have expected count less than 5 . The minimum expected count is 26.74 .

\section{$Y=\beta_{0}+\beta_{1} X_{1}+\beta_{2} X_{2}+\beta_{3} X_{3}+\beta_{4} X_{4}+\varepsilon$}

Where $Y=$ Technology Acceptance, $\beta_{0}=$ Constant, $\beta_{1 \ldots .}=$ Coefficients of the variables, $X_{1}=$ Disposition, $X_{2}=$ Perceived risk, $\mathrm{X}_{3}=$ Website Dimensions and e-trust, $\mathrm{X}_{4}=$ Self-efficacy and $\mathcal{E}=$ Error term.

The ordinal regression model results are presented in form of tables that show the model goodness of fit, $\mathrm{P}$ values, anova and $\mathrm{R}^{2}$. This was useful in depicting the relationships between the independent, mediating and dependent variables in the research and more so demonstrated whether the anticipated relationships being examined by the researcher are positive or negative.

\section{Discussion}

From our statistics we found out that the people who have never made any online transaction which were found to be approximately 1450 only perceived risks of the e-economy is more acute to the 1514 of the number found to have transacted, our hypotheses for the research study will be as follows.

Hypothesis One: the overall perception risks of people who have not carried out any online transaction is higher than those that have carried out the transaction. This is more applicable to Ivory coast than China. This was confirmed by p value $<0.05$ in the table below. From table 4.1 no cell is less than 5 were observed this showed that there is strong association Education and perception to carry out online transaction. The $p$ value is less than 0.05 . hence there was significance relationship. Table 4.2 confirmed the strong association as the approximate $p$ value $<0.05$.

Hypothesis Two: The overall perceptional risk of the male population is higher than the female's population this could be due to the fact that female population are less educated on computer skills. More have access to online transition than female it can as well be attributed to traditional believes that view technology as evil in underdeveloped countries.

There was significant association between technology and education as well from table 4.4 majority acquired primary education. As $\mathrm{p}$ value $=0.002$.

Hypothesis Three: The overall perceptional risks of both male and female are significantly the same not unless their level of education and income is taken into account. Male number $=310$ while female $=308$ no significant difference. As shown in table 4.5.

Online payment: Male vs. Female

There was significance in association between gender and education was observed on masters and PhD. Hence, this could to access to the resources such as computer and internet.

Hypothesis Four: The overall perceptional risk of individuals people with high income differs significantly with the people of low income this is because the high-income part of the population is well conversant with the modern trends in technology than the low income hence there would be great knowledge on the e-commerce. Table 4.6 shows that no cells have expected count less than 5 on all the scale. 
Hypothesis Five: the overall perceptional risks of the people with higher educational level differs significantly with the lower level of education mostly because the higher level of education is well informed on the latest technologies and modern trends hence, they are fully aware of what they are getting into, unlike the lower level of education who are still naïve.

There is weak correlation between fear on online transaction and education. Individuals will carry transactions as long as they get payments. From the table above, it can be seen that the correlation is below $r=0.4$, this depict weak link between education and online transaction fear and $\mathrm{p}$ value $>0.05$.

Hypothesis Six: the perceptional risks of the youth and the elderly doesn't differ that greatly unless their level of education and income are put to consideration. Since the table 4.8 shows 2 -tail test the $\mathrm{p}$ value will be halved to get $0.6>0.05$. Thus, depict no significant difference in age and risk.

Hypothesis Seven: The overall perceptional risks of both the youth and the elderly who have transacted both online differ a bit because as we can see the older populations were so much used to the traditional ways hence coping with the trend like the youths is somewhat difficult.

The results quite varied from the different groups of the population and were subject to dishonest answers from other people as seen in table 4.9. Taking into consideration that the researcher faced a lot of challenges the data may not be $100 \%$ unlike other methods of data collection because of lack of proper technology put in place to make sure that the questionnaires reached a lot of people.

\section{Conclusion}

It can be concluded that perceptional risks among consumers differ from various groups of individuals, and that they are mostly affected by certain factors such as age, income and gender. From the study, about half the population prefer the tradition ways rather than embracing the modern trends of technologies to purchase the required commodities. The research was subjected to a lot of limitations, but the data were sufficient to obtained reliable results that can be used to form a proper statistical framework for the study. Although Ivory coast is making significant technological progress, perceptional risks among the consumers concerning e-commerce and online self-efficacy influence the citizens' ability to embrace technology. On the other hand, China's reliance on technology is growing steadily as Chinese are moving away from the traditional shopping habits to e-commerce (Tan, 2016). That was a research study concerning the technology acceptance model in China and Ivory Coast and how they affect their respective national economy.

\section{Recommendations for Further Study}

This study focused of a few factors affecting an individual's acceptance of the e-commerce technology on just countries with different levels of economies. Further research can be conducted on other developing countries in the region while focusing on other factors that could responsible for variance in technology acceptance.

\section{References}

Agarwal, R. and J. Prasad, 1999. (1999). Are individual differences germane to the acceptance of new information technologies. Decis. Sci, 30, 361-391.

Ajzen, I. (2002). Perceived behavioral control, self-efficacy, locus of control, and the theory of planned behavior. Journal of Applied Social Psychology, 32(4), 665-683.

Ajzen, L., \& Fishbein, M. (1980). Understanding attitudes and predicting social behavior. Prentice Hall Inc.

Amin, Hanudin. (June 18, 2007). Is the Technology Acceptance Model Valid for Bimb Mobile Banking? An Empirical Analysis International Journal of e-Business Management, 1(1), 33. 
Bitner, M.J., Zeithaml, V.A. \& Gremler, D.D, Kieliszewski, C.A. \& Spohrer, J.C. (2010). Technology’s impact on the gaps model of service quality. Handbook of service science, 197-218.

Cassell, J., Bickmore, T., H, Vilhjálmsson, and Yan, H. (2000). More Than Just a Pretty Face: Affordances of Embodiment. In Proceedings of the 5th International Conference on Intelligent User Interfaces, 52-59.

Chau, P. Y. (2001). Influence of computer attitude and self-efficacy on IT usage behavior. Organizational and End User Computing, 13(1), 26.

Chen, L., Gillenson, M., \& Sherrell, D. (2002). Enticing online consumers: An extended technology acceptance perspective. Information and Management, 39, 706-719.

Dasgupta, S., Granger, M. and McGarry, N. (2002). User acceptance of e-collaboration technology: an extension of the technology acceptance model. Group Decisions and Negotiations, 11(2), 87-100.

Davis F., Bagozzi R., and Warshaw P. (1989). User acceptance of computer technology: A comparison of two theoretical models. Management Science, 8(54), 982-1003.

Davis, F., Bagozzi, R., Warshaw, P. (1989). User acceptance of computer technology: a comparison of two theoretical models. Manag. Sci., 35(8), 982-1003

Davis FD, Bagozzi RP, Warshaw PR. (1989). User acceptance of computer technology: a comparison of two theoretical models. Manage. Sci, 35(8), 982-1003.

Dishaw, M.T. and Strong, D.M. (1999). Extending the technology acceptance model with task-technology fit constructs. Information \& Management, 36(1), 9-21.

Gefen, D. and Straub, D. (2000). The relative importance of perceived ease-of-use in IS adoption: a study of ecommerce adoption. AIS, 1(8), 1-28.

Jahangir, N. and Begum, N. (2008). The Role of Perceived Usefulness, Perceived Ease of Use, Security and Privacy, and Customer Attitude to Engender Customer Adaptation in the Context of Electronic Banking. African Journal of Business Management, 2, 32-40.

Jeong, B. K., \& Yoon, T. E. (2013). An empirical investigation on consumer acceptance of mobile banking services. Business and Management Research, 2(1), 31.

Kock, J. . (2017). Technology acceptance model (tam). an overview. GRIN Publishing.

Laforet, S., \& Li, X. . (2005). Consumers' attitudes towards online and mobile banking in China. International Journal of Bank Marketing,, 23(5), 362-380.

Lederer, A.L., Maupin, D.J., Sena, M.P. and Zhuang, Y. . (2000). The Technology Acceptance Model and the World Wide Web. Decision Support Systems, 29, 269-282.

Liao, Z., \& Wong, W. K. The determinants of customer interactions with internet-enabled e-banking services. Journal of the Operational Research Society, 59(9), 1201-1210.

Liao, Z., \& Wong, W. K. (2007). (2007). The determinants of customer interaction with internet-enabled ebanking services. The department of Economics.

M. A. Radwan, and A. K. Mumtaz. (2010). Business -to- consumer e-commerce Web Sites: Vulnerabilities, Threats and quality evaluation mode. International Conference on Electronics, Communications, and Computers - CONIELECOMP

McCarthy, N. (2018). China Now Boasts More Than 800 Million Internet Users And 98\% Of Them Are Mobile. Forbes.

Myktyin, P., Harrison, D., \& David, A. . (2003). The application of the TRA to strategic management and strategic information systems. Resources Management Journal, 6(2).

Özdemir, Ö., \& Şehitoğlu, Y. (2013). Assessing the Impacts of Technology Business Incubators: A framework for Technology Development Centers in Turkey. Procedia - Social and Behavioral Sciences,, 75, 282291. doi: doi: 10.1016/j.sbspro.2013.04.032

Padachi, al et. (2008). Investigating into the factors that influence the adoption of internet banking in Mauritius. Proceedings of the 2007 Computer Science and IT Education Conference.

Pikkarainen, T. (2004). Customer acceptance of online banking": An extension of the Technology Acceptance Model. Internet Research, 16(2).

Saadé, R., \& Bahli, B. (2005). The impact of cognitive absorption on perceived usefulness and perceived ease of use in on-line learning: An extension of the technology acceptance model. Information \& Management, , 42(2), 261-386.

Safeena, al et. (2010). Customer Perspectives on E-business Value: Case Study on Internet Banking. Journal of Internet Banking and Commerce, 15(1).

Straub, D.W., Keil, M. and Brenner, W. (1997). Testing the technology acceptance model across cultures: a three country study. Information \& Management, 33(1), 1-11.

Swaid, S.I. and R.T. Wigand. (2007). Key dimensions of E-commerce service quality and its relationships to satisfaction and loyalty. . Proceedings of the 20th Bled e-Conference e-Mergence: Merging and Emerging Technologies, Processes and Institutions, 414-423. 
Taherdoost, H. (2018). Development of an adoption model to assess user acceptance of e-service technology: EService Technology Acceptance Model. Behavior \& Information Technology, 37(2), 173-197. doi: doi: 10.1080/0144929x.2018.1427793

Tan, J., \& Ludwig, S. (2016). Regional Adoption of Business-to-Business Electronic Commerce in China. International Journal of Electronic Commerce, 20(3), 408-439. doi: doi: 10.1080/10864415.2016.1122438

Taylor, S. and P.A. Todd. (1995). Understanding information technology usage: A test of competing models. Inform. Syst. Res., 6, 144-176.

Triandis, H.C. (1979). Values, Attitudes, and Interpersonal behaviour. Nebraska Symposium on Motivation: Beliefs, Attitude, and Values. University of Nabraska Press, 195-259.

Venkatesh. (2000). Determinants of perceived ease of use: integrating control, intrinsic motivation, and emotion into the technology acceptance model. Info. Syst. Res, 4(4), 342-365.

Venkatesh, Davis F.D. (2000). A theoretical extension of the technology acceptance model:

four longitudinal studies. Management Science, 46(2), 186-204.

Venkatesh V., Michael. G. M., Gordon. B. Davis., Fred D. (2003). User acceptance of information technology: Toward a unified view. MIS Quarterly, 27(3), 425-478.

Weber and C.K. Hsee, E.U. . (1998). Cross-cultural differences in risk perception, but cross-cultural similarities in attitude towards perceived risk. Management Science, 44(9), 1205-1214.

\section{QUESTIONNAIRE}

The samples will be dived into two main groups namely the group that have participated in the e-commerce be it once or more and the group that have never made any online transaction in their lifetime hence the questions of each groups would differ significantly because of their first reply.

Q1. Have you ever used the internet to carry out any transaction? (Yes/No). Furthermore, we would like to know why the respondent hasn't carried out any online transactions. Hence, we would further ask these questions.

Q2.1. Do you have access to the internet? (Yes/No)

Q2.2. I believe that I will get the quality I expected? (Strongly agree, Agree, Neutral, Disagree, strongly disagree)

Q.2.3. I have never transacted online because I don't have a computer? (Strongly agree, Agree, Neutral, Disagree, strongly disagree)

Q.2.4. I have never transacted online because the transaction will all be just as scam and never get results. (Strongly agree, Agree, Neutral, Disagree, strongly disagree)

Q.2.5. I have never transacted or bought goods online because the time of delivery would be breached. (Strongly agree, Agree, Neutral, Disagree, strongly disagree)

Q.2.6. I don't trust that my payment credentials won't be badly used after the transaction has taken place. (Strongly agree, Agree, Neutral, Disagree, strongly disagree)

Q.2.7. I have never transacted online because I fear that the quoted price isn't the real price. (Strongly agree, Agree, Neutral, Disagree, strongly disagree)

The first part of the questionnaire addressed respondents that answered no in the first question posted towards them all. These next sections will address those respondents that answered yes to the question posted towards them first; hence the following are there specific questions.

Q.3. I have good internet connection. (Strongly agree, Agree, Neutral, Disagree, strongly disagree) 
Q.4. My internet connection affects my online activities. (Strongly agree, Agree, Neutral, Disagree, strongly disagree)

Q.5. I fear that my computer will get attacked by a virus during the online transaction limits, my online transactions. (Strongly agree, Agree, Neutral, Disagree, strongly disagree)

Q.6. I don't use online transaction frequently because the details about a product offered online won't match its physical features. (Strongly agree, Agree, Neutral, Disagree, strongly disagree)

Q.7. I don't transact more on the internet because I fear sharing personal details in the fear that there is no privacy in the web (Strongly agree, Agree, Neutral, Disagree, strongly disagree)

Q.8. I do not use the internet frequently to carry out transactions because the power and internet accessibility isn't reliable. (Strongly agree, Agree, Neutral, Disagree, strongly disagree)

This last chapter of the questionnaire would be used for identification, grouping and clarification purposes of the audience or respondents.

\section{Q.9. Gender (Male/Female)}

Q.10. Level of education (primary/secondary/tertiary/certificate/degree/masters/diploma/phd)

Q.11. Age (10/20/30/40/50/60/).

\section{ACKNOWLEDGEMENT}

First, I would like to thank Jehovah God for his guidance and the power he has given me to complete this article. I would like to express my deepest gratitude to my father and mother Guillaume and Jeannette Akouatcha without forgetting my brothers Pascal-Romuald, Guy-Youval and Régis-Claude Akouatcha for their love and support. I want to thank my friend and my partner Ingrid Epezagne for her encouragement. In addition, I want to show my great appreciation to my supervisor, Professor 李治文 of Jiangsu University and Professor Essien Daniels of Graduate school of Management in Abidjan (GSM) for their invaluable advice, guidance and encouragement during the writing of this article. They provided many useful comments and suggestions for the preparation of this article. Moreover, I want to thank my countrymen's and friends of Jiangsu university. My grateful thanks also go to the person of Sr Berthé Tiemoko representative of the Minister Bruno Nabagné Koné formerly holder of the ministerial of Digital Economy and Post Now Minister of Construction, Housing, Sanitation and Urban Development. In addition, I want to express my gratitude to the interview participants who offered their valuable time, which helped me conduct this research. 